\title{
Sergio Valerio Ulloa, Los barcelonnettes en Guadalajara, siglos XIX y XX, Universidad de Guadalajara/Instituto de Investigaciones Dr. José María Luis Mora/Consejo Nacional de Ciencia y Tecnología, 2015, 574 pp.
}

\author{
Carlos Marichal*
}

2 de marzo de 2018

\begin{abstract}
$\mathrm{N}^{\circ}$ es muy frecuente en la historia empresarial contar con una documentación suficientemente rica para reconstruir tanto la vida y obra de determinados individuos y familias, como la de toda una comunidad. En el caso del presente libro de Sergio Valerio se trata un estudio de la comunidad de los empresarios de origen francés conocidos como los barcelonnettes en la ciudad de Guadalajara desde mediados del siglo XIX hasta principios del siglo XX. En los primeros decenios del siglo XIX, los emigrantes del valle de Barcelonnette en los Bajos Alpes llegaban realmente a cuentagotas a México. Pero posteriormente comenzaron a arribar en mayor número, hasta el punto que en 1910 hubo unos 6000 franceses residentes en México, de los cuales se calcula que posiblemente las tres cuartas partes eran barcelonnettes, la mayoría dedicados al comercio de telas, pero en ocasiones combinando otros intereses como la industria y la banca. Fueron fundadores de algunas de las mayores empresas y almacenes de textiles en el país, y su descendencia aún es partícipe hoy en día, en determinados casos, de grandes empresas como las de Liverpool y Palacio de Hierro, entre otras.

El estudio de Sergio Valerio tiene dos objetivos centrales en esta obra. En primer lugar, se trata de la reconstrucción de la historia social y económica de una comunidad de inmigrantes franceses de extraordinaria vitalidad y, por qué no decirlo, de creatividad empresarial. En segundo lugar, se trata de analizar lo que el autor llama los "discursos e imágenes de la modernidad" a partir de testimonios escritos y visuales, especialmente fotografías, de este grupo importante de franceses mexicanos en Guadalajara, en la segunda mitad del siglo XIX y principios del
\end{abstract}

*El Colegio de México 
XX, incluyendo la revolución. En esta segunda parte del libro se combina el análisis del espacio empresarial con la vida cotidiana. En realidad, el trabajo constituye un excelente ejemplo de los puentes que se pueden tender entre historia económica, social y cultural. Es importante en tanto que, en ocasiones, la nueva historia económica ha resultado tan cuantitativa y economicista, que se olvida de los principales atractivos del campo de la historia económica para un público lector amplio, y es el que consiste en ofrecer un panorama vinculante entre la economía y la sociedad, política y cultura.

En el primer capítulo, el autor ubica a la comunidad de los barcelonnettes que llegaron a Guadalajara en el siglo XIX, y proporciona una detallada información demográfica que se basa en padrones de la ciudad que ha localizado y analizado. Esta información la pone en el contexto de la emigración más general a México, con series de datos por nacionalidades de gran interés. En el mismo capítulo el autor describe el valle de Barcelonnette en los Bajos Alpes, de donde salieron los miles de personajes de esta historia. Estos se movieron en el contexto de las cadenas de emigración que han sido tan importantes en la historia y que siguen siéndolo en el caso de las emigraciones contemporáneas de otros grupos sociales a escala mundial; no hace falta recordar las cadenas de poblanos, oaxaqueños y zacatecanos que han emigrado a destinos puntuales en Estados Unidos a lo largo de los últimos decenios de nuestra época. Típicamente, la cadena consiste en que después de la emigración exitosa de un pequeño núcleo de individuos a otro país o región, se establece un impulso para el mantenimiento y reforzamiento de lazos dinámicos entre la localidad expulsora de emigrantes y la comunidad en el exterior. Dichos lazos consisten en que suele generarse una demanda para que sigan emigrando jóvenes y se unan a la comunidad y sus proyectos empresariales en el lugar de recepción. En su mayoría los barcelonnettes que emigraban a Mexico -y más específicamente a Guadalajara- eran jóvenes y mayoritariamente hombres, quienes pronto se involucraban en negocios vinculados a sus compatriotas. Ahora bien, también existían otros lazos hacia atrás; por ejemplo, en algunos casos -aunque no la mayoría- también emigraban mujeres de Barcelonnette que luego se casarían en México con compatriotas.

A su vez, al llegar a la vejez, existió siempre un cierto número de emigrantes que regresaban a casa, en general habiendo acumulado suficientes ahorros para poder pasar el resto de sus días con cierta comodidad en el valle de origen en los Bajos Alpes. Pero como señala Valerio en la introducción al libro, la mayoría de los inmigrantes no llegaron a gozar de esta prosperidad, sino que vivieron vidas duras, explotados por sus patrones, tema al que regresa en el cuarto capítulo del libro.

En el capítulo segundo y tercero, el autor nos describe gran parte de las principales empresas que fundaron, la mayoría almacenes de telas, pero también establecimientos fabriles que los abastecían, para complementar las importacio- 
nes de Francia y para la confección. Los nombres de las firmas son llamativos: El Palacio de Cristal, El Sombrero Colorado, La Gran Sombrerería Francesa, La Ciudad de Londres, La Feria de San Juan de los Hermanos Letaud, La Ciudad de París, Las Fábricas de Francia de Fourtul, Chapuy y Cía., El Nuevo Mundo, Las Fábricas de Lyon y Las Fábricas Universales. El autor también estudia otras entidades, La Bolsa Mercantil, El Círculo Francés, empresas de pastelería, y agrega como colofón, descripciones de las fiestas que solían organizar los barcelonnettes en Guadalajara.

En el capítulo cuarto Sergio Valerio analiza las relaciones entre los patrones y empleados en los almacenes comerciales, con base en listas de empleados, correspondencia y fotos. Se trataba de grupos de patrones y empleados que formaban comunidad, pero al mismo tiempo estaba cruzada por las tensiones del trabajo, de la explotación, de la desigualdad en riqueza y bienestar.

En el capítulo sexto el autor cambia un tanto el rumbo de la investigación y explora los puentes ente historia empresarial e historia cultural e historia de la moda, cuyo subtítulo es especialmente sugerente: "La moda a través de las vitrinas de la modernidad", donde se explica la evolución de las cambiantes formas de la moda a través del siglo XIX, para luego entrar al tema de la publicidad. ¿Cómo se proyectaban o publicitaban las telas y trajes que vendían los barcelonnettes? Pues resulta que aquí la prensa era uno de los medios más importantes, y de allí arranca una forma importante de financiamiento de los periódicos de la época, que ya dejan de ser simples vehículos políticos y se convierten también en instrumentos de la nueva cultura de consumo. A través de la exploración de los periódicos, Juan Pandero, Diario de Jalisco, El Regional, La Gaceta de Guadalajara, El Bien Público, Jalisco Libre y El Informador, entre 1880 y 1930, Sergio Valerio logra agregar un capítulo muy colorido, detallista y elegante a su libro, e introduce a la mujer como consumidora clave en esa sociedad.

En el capítulo séptimo se presentan muchas facetas de la vida cotidiana, y en este caso, lo más original es el descubrimiento de las cartas de los barcelonnettes, una buena parte que encontró guardadas en el Musée de la Vallée de Barcelonnette, en Francia. El autor ofrece unas penetrantes observaciones sobre el género epistolar -en camino de fenecer en nuestra época- y señala que hay que leer esta correspondencia desde un conocimiento de contexto y personas, pero que son muy ilustrativas como documentos de la vida cotidiana. El capítulo 8 da testimonio de un extraordinario descubrimiento, el diario de Eugen Cuzin, un dueño de almacén que relata lo que ocurre durante la revolución, con villistas, carrancistas y muchos otros que invaden la ciudad, luego salen, con la interrupción del comercio, con los robos, la violencia y la pobreza. 
Finalmente, el libro se cierra con un capítulo luminoso sobre la fotografía de los barcelonnettes y de muchos más en Guadalajara, en esa época tan dura pero tan interesante. La colección de fotos incluidas constituye una excelente forma de acercarnos a esta historia fascinante que relata Sergio Valerio. 